Urszula Miernik

Uniwersytet Opolski

\title{
Rozwód w prawie \\ Polskiego Autokefalicznego Kościoła Prawosławnego: ewolucja instytucji w XX wieku
}

Rozwiązanie małżeństwa w perspektywie historycznej podlegało prawu świeckiemu i religijnemu. Związane było zwykle z wystąpieniem przeszkód, które uniemożliwiały realizacje „celu, dla którego instytucja [małżeństwa] została stworzona"'. Rozwód jest jedną z form rozpadu małżeństwa, jest procesem zależnym od zewnętrznych czynników, takich jak zmiany społeczne, przyjmujące również formę kryzysów społecznych, podczas których ludzie „samoczynnie dostosowują swe zachowania w sferze matrymonialnej, [...] do nowych warunków", przykładowo odraczając lub przyspieszając decyzje o zmianie stanu cywilnego $^{2}$.

Rozwód w optyce współczesnego polskiego prawa jest rozwiązaniem małżeństwa za życia małżonków i, co istotne, $\mathrm{z}$ możliwością zawarcia przez każdą ze stron nowego legalnego związku. Przesłanką rozwiązania małżeństwa jest trwały i zupełny rozkład pożycia, jeśli nie wystąpią sytuacje zagrażające dobru dziecka. Według przepisów prawa polskiego rozwód także nie może stać w sprzeczności z zasadą współżycia społecznego ( $\$ 56$ ust. 2 k.r.o. $\left.{ }^{3}\right)$ polegającą na „synchronizowaniu przepisów prawa z nakazami moralności i obyczajów”4.

J. Strzebińczyk, Prawo rodzinne, Warszawa 2013, s. 154.

2 P. Szukalski, Małżeństwo. Początek i koniec, Łódź 2013, s. 19.

3 Ustawa z dnia 25 lutego 1964 r. Kodeks rodzinny i opiekuńczy (Dz.U. nr 9, poz. 59 z późn. zm.), tu: art. 56 [dalej: k.r.o.].

4 Uchwała pełnego składu izby cywilnej sądu najwyższego z dn. 18 marca 1968 r. Wytyczne. 
Zasada ta odwołuje się do doświadczeń prawno-obyczajowych społeczeństw, które w procesie rozpadu małżeństwa pełnią ważną rolę. Związane z tymi doświadczeniami normy obyczajowe i prawne mogą opierać się na normach moralnych oraz religijnych. Te ostatnie $\mathrm{z}$ kolei, jeśli są zbieżne $\mathrm{z}$ normami prawa państwowego, mogą podnosić jego efektywność, jeżeli wpływ religii na dane społeczeństwo jest znaczący

W okresie międzywojennym zmiany ustrojowe Kościoła prawosławnego w Polsce przyniosły początek nowym relacjom prawnym z państwem polskim. Wymagały one między innymi wyznaczenia zakresu władzy państwa i Kościoła nad instytucją małżeństwa. Kształtowanie się nowego prawa Kościoła przebiegało w kontekście procesu kodyfikacji i unifikacji polskiego prawa małżeńskiego. Komisja kodyfikacyjna musiała zmierzyć się z różnymi systemami prawnymi obowiązującymi na terenach Rzeczpospolitej, a także z krytyką środowiska katolickiego dotyczącą projektu instytucji rozwodu w nowym prawie. Należy dodać, że w latach 1936-1938 skala rozwodów w Polsce była nieznaczna, rozpadały się 4 małżeństwa na $1000^{7}$.

Polski Autokefaliczny Kościół Prawosławny dopuszczał rozwód w swoim prawie, stąd też nadchodzące zmiany prawa małżeńskiego nie budziły obaw władz Kościoła. Prawo wewnętrzne, odnosząc się do dogmatów Kościoła, było także ugruntowane w rzeczywistości ziemskiej, przykładem tego są statuty Polskiego Autokefalicznego Kościoła Prawosławnego. Pierwszym dokumentem, także najobszerniej opisującym zasady rozwiązania prawosławnego małżeństwa, był Statut Konsystorzy Diecezjalnych Świętego Polskiego Autokefalicznego Kościoła Prawosławnego z 1939 r. W kolejnych dekadach Kościół dokonał zmian przepisów rozwodowych dwukrotnie - w $1970 \mathrm{r}$. oraz w $1995 \mathrm{r}$. W niniejszej pracy omówione zostanie zagadnienie rozwodu w świetle przepisów kościelnych Polskiego Autokefalicznego Kościoła Prawosławnego z odniesieniem do prawa zasadniczego Kościoła prawosławnego, tj. Pisma Ŝwiętego, kanonów apostolskich, oraz kanonów soborów powszechnych i lokalnych.

5 P. Szukalski, Małżeństwo. Początek i koniec, dz. cyt., s. 19.

6 S. Wronkowska, Z. Ziembiński, Zarys teorii prawa, Poznań 2011, s. 89.

7 Główny Urząd Statystyczny, Historia Polski w liczbach, red. C. Kuklo, J. Łukasiewicz, C. Leszczyńska, Warszawa 2014, s. 116. 


\section{Rola prawa kanonicznego małżeńskiego w Kościele prawosławnym}

Stosunek Kościoła ortodoksyjnego do własnego prawa kanonicznego ${ }^{8}$ oddają następujące słowa: „Królestwo Boże nie ma mocy przymusu prawnego, a przedstawia swobodny wybór ludzki. Ewangelia nie sprowadza misterium wolności ludzkiej do przepisów prawnych. Ona zaleca tylko człowiekowi dar godny - doskonałość"’". Prawo Kościoła prawosławnego jest ściśle związane z pierwotnym Kościołem świętych apostołów i ojców Kościoła. Świadomość powołania do troski o prawo Boże w świecie predysponuje Kościół prawosławny do ustanawiania kanonów oraz do władzy sądzenia i sankcjonowania prawa w koniecznych przypadkach. Charakter kanonu wyrażają jego normy, których celem jest ochrona porządku prawno-moralnego skierowana do duchownych Kościoła, jak i wiernych świeckich ${ }^{10}$. Kanony Kościoła prawosławnego, według Paula Evdokimova, są interpretacją dogmatów w konkretnym czasie historycznym, ponieważ celem jest pomoc wiernym we wprowadzeniu do swojego życia tych dogmatów ${ }^{11}$. W ustalaniu kanonów nie tylko czas historyczny odgrywa znaczącą rolę, lecz ważne jest także miejsce funkcjonowania społeczności Kościoła, stąd kanony „wyznaczają widzialny kształt Kościoła lokalnego" ${ }^{\prime 2}$ w zjednoczeniu w dogmacie ze wszystkimi siostrzanymi Kościołami prawosławnymi ${ }^{13}$, bowiem przyjmuje się, że ,jedność wiary i kultu może wyrażać się na różne sposoby"14.

Kościół prawosławny w Polsce stał się niezależnym Polskim Autokefalicznym Kościołem Prawosławnym w 1924 r. ${ }^{15}$ Ogłoszenie tomosu o autokefalii

${ }^{8}$ Kościół prawosławny nie posiada jednolitego skodyfikowanego prawa kanonicznego, tak jak jest to w prawie Kościoła rzymskokatolickiego, zob. szerzej E. Przekop, Problem wspólnego Kodeksu Prawa Kanonicznego dla kościołów prawosławnych, „Studia Płockie” (1977), s. 173-183.

9 S. Hrycuniak, Prawosławne pojmowanie małżeństwa, Białystok 1994, s. 34.

${ }^{10}$ A. Znosko, Kanony kościoła prawosławnego, Hajnówka 200o, s. 5.

11 P. Evdokimov, Prawosławie, Warszawa 2003, s. 198.

${ }^{12}$ „Kościół lokalny jest wspólnotą eucharystyczną, zgromadzoną wokół swego biskupa na jednym miejscu”, w praktyce dotyczy to diecezji. Katechizm Kościoła Prawosławnego, Kraków 2001, s. 370.

13 P. Evdokimov, Prawosławie, dz. cyt., s. 197.

${ }^{14}$ P. Evdokimov, Prawosławie, dz. cyt., s. 197.

1513 listopada 1924 r. Patriarcha Konstantynopolski Grzegorz ogłosił autokefalię Kościoła prawosławnego w Polsce. Została ona uroczyście proklamowana we wrześniu 1925 r. na Warszawskim Soborze Metropolitalnym, zob. L. Z., Śladem dawnej tradycji, „Przegląd Prawosławny. Organ Polskiego Prawosławia” (1939) nr 1, s. 5. Dekretem o stosunku Państwa do Polskiego Autokefalicznego Kościoła 
Kościoła zwyczajowo wiązało się z tym, aby „prawa, odnoszące się do spraw kościelnych, a przede wszystkim do spraw parafialnych, stosowano do zmian politycznych i administracyjnych"16. Dla Kościoła prawosławnego w Polsce oznaczało to ułożenie stosunków z państwem polskim ${ }^{17}$ oraz konieczność nowej organizacji wewnętrznej Kościoła. Związana ona była $\mathrm{z}$ działaniem „w niezależności hierarchii Kościoła w danym państwie od hierarchii Kościoła znajdującego się w innym państwie, w istnieniu odrębnego prawodawstwa oraz w zachowaniu lokalnych zwyczajów i obrzędów kościelnych"18. Dla duchowieństwa prawosławnego autokefalia wiązała się z rozpoczęciem „nowej ery”, dawała „podstawę do normalnego rozwoju oraz możność dalszej ewolucji i dostosowania się do nowych potrzeb i warunków”"19. W stosunkach między państwem a Kościołem wyznawano zasadę symfonii czyli współdziałania dla wspólnego dobra. Idee prawa, które przyświecały Kościołowi prawosławnemu, wpłynęły w kolejnych latach na kształt prawa małżeńskiego, w tym instytucji rozwodu.

Myśląc o prawosławnym prawie małżeńskim, należy mieć na uwadze dwie wartości przynależne małżeństwu: kanoniczną i religijną. Istotą pierwszej $\mathrm{z}$ nich jest rozumienie małżeństwa jako instytucji prawnej, z której wynikają wzajemne obowiązki oraz prawa małżonków. Takie małżeństwo jest fundamentem społeczeństwa i państwa. Małżeństwo uznawane za ważną instytucję prawną, co podkreśla jego znaczenie w życiu społecznym, może osiągnąć ideał tylko w połączeniu $\mathrm{z}$ religią ${ }^{20}$. Zadaniem prawa kanonicznego jest ochrona małżeństwa „zarówno w boskiej, jak i ludzkiej rzeczywistości”21. Małżeństwo,

Prawosławnego regulującym położenie Kościoła w państwie polskim w 1938 r. wprowadzono nową nazwę: Polski Autokefaliczny Kościół Prawosławny; zmiana ta podkreśliła polskość Kościoła, dawną zaś uważano za odnoszącą się do obszaru działalności Kościoła, zob. D. Balejko, Nowa podstawa prawna Kościoła prawosławnego w państwie polskim, „Przegląd Prawosławny. Organ Polskiego Prawosławia" (1939) nr 1, s. 7.

${ }_{16}$ Tekst tomosu zamieszczony został w: T. Płoński, Tomosy z 1924 i 1948 roku nadające status autokefaliczny Polskiemu Autokefalicznemu Kościołowi Prawosławnemu: ich wydźwięk historyczno-kanoniczny, „Studia Warmińskie” 46 (2009), s. 153-171.

${ }^{17}$ Art. 115 Konstytucji z 1920 r. stanowił, że Kościoły religii mniejszościowych (prawosławie stanowiło 10,5\% społeczeństwa II Rzeczpospolitej w 1921 r.) mogą rządzić się własnymi ustawami, o ile te nie są sprzeczne $\mathrm{z}$ prawem państwowym.

${ }_{18}$ Tomos to akt o uznaniu autokefalii Kościoła prawosławnego; zob. szerzej M. Papierzyńska-Turek, Między tradycją a rzeczywistością. Państwo wobec prawosławia 1918-1939, Warszawa 1989, s. 103-120.

19 L. Z., Śladem dawnej tradycji, dz. cyt., s. 5.

${ }_{20}$ S. Hrycuniak, Prawosławne pojmowanie małżeństwa, dz. cyt., s. 18.

${ }^{21}$ J. Meyendorff, Małżeństwo w prawosławiu, tłum. K. Leśniewski, Lublin 1995, s. 39. 
będąc ideałem świętym, równocześnie przynależy do świata nazwanego przez Sawę Hrycuniaka upadłym światem, stąd powstała konieczność zabezpieczenia go poprzez ustalenie kanonów, które nigdy w Kościele prawosławnym nie były celem same w sobie ${ }^{22}$. Głównym założeniem prawa kanonicznego była ochrona moralnej czystości i świętości i ideału małżeństwa ${ }^{23}$.

W stosowaniu prawa Kościół prawosławny przyjmuje zasadę ekonomii kościelnej. Zostało to podkreślone w najnowszym nauczaniu Kościoła na Soborze Wszechprawosławnym, kiedy odniesiono się do stosowania ekonomii kościelnej wobec małżeństwa, przyznając każdemu autokefalicznemu Kościołowi prawosławnemu autonomię, mającą na celu troskę duszpasterską o zbawienie człowieka (II, 7) $)^{24}$. Ekonomia Kościoła, rozumiana czasem jako pobłażliwość w stosunku do rozwiedzionych małżonków, znajduje głębsze wyjaśnienie w samej ekonomii zbawienia, bowiem „[p] rawda człowieka jest wcześniejsza od jego rozdwojenia i to ona zaczyna dominować $\mathrm{z}$ chwilą, gdy człowiek zakorzenia się w Chrystusie"25. Celem ekonomii kościelnej jest więc uzdrowienie człowieka poprzez pojednanie i pokutę, ponieważ trwając w upadku, nie tylko nie może wzrastać, lecz pozbawiony zostaje swojej natury. Zaś w sensie jurydycznym ekonomia jest uprawnieniem biskupa do zachowania ogólnego przepisu kanonu, czyli pozostawania przy doktrynie z jednoczesną tolerancją sprowadzającą się do tego, by w niektórych sytuacjach pominąć normy lub traktować je nieco luźniej ${ }^{26}$.

\section{Nierozerwalność małżeństwa w prawie Kościoła prawosławnego}

Uzasadnienie nierozerwalności małżeństwa prawosławnego znajduje się $\mathrm{w}$ teologii, bowiem źródłem małżeństwa w prawosławnym rozumieniu jest prawo Boże: „od samego początku było [małżeństwo] nie tylko naturalnym, ale i duchowym, moralnym nierozwiązalnym związkiem trwałej, wzajemnej,

${ }^{22}$ S. Hrycuniak, Prawosławne pojmowanie małżeństwa, dz. cyt., s. 130.

${ }_{23}$ S. Hrycuniak, Prawosławne pojmowanie małżeństwa, dz. cyt., s. 87.

${ }^{24}$ A. Kuźma, Małżeństwo w projektach dokumentów na Wszechprawosławny Sobór, „ELIPs” 18 (2016), s. 177-182.

${ }^{25}$ P. Evdokimov, Kobieta i zbawienie świata, Poznań 1989, s. 82.

${ }^{26}$ T. Kałużny za: W. Hryniewicz, Zasada „ekonomii eklezjalnej” w życiu i teologii prawosławia, „Roczniki Teologiczno-Kanoniczne” 28 (1981) z. 6, s. 137-152, [w:] Nierozerwalność matżeństwa w Kościele prawosławnym, „Sympozjum” (2010) nr 1(19), s. 41-6o. 
wiecznej miłości, tworzącym «jedno ciało» (1 Mojż. 1, 24)"27. Podstawą teologii małżeństwa stały się słowa św. Pawła dotyczące nierozerwalności związku Jezusa Chrystusa z Kościołem ${ }^{28}$. Małżeństwo nie jest symbolem tej relacji, lecz faktycznie „uobecnia to misterium jedności i je urzeczywistnia” ${ }^{29}$. Nawiązanie do związku Chrystusa z Kościołem jako „tajemniczego wzorca jedności mężczyzny i kobiety" zostało także wyrażone w prawosławnej liturgii zaślubin w części zwanej anamnezą ${ }^{30}$.

Małżeństwo posiada swoją „autonomiczną wartość”, zaś jego pierwszym celem jest miłość małżonków ${ }^{31}$. Służy ono co prawda zaspokojeniu potrzeb związanych z ziemskim bytem człowieka, ale przede wszystkim pozwala człowiekowi wejść do „Królestwa życia wiecznego”32. Wykracza poza rzeczywistość życia ziemskiego i nie zostaje przerwane przez śmierć, bowiem „miłość nigdy nie ustaje" (1 Kor 13, 8). Kościół prawosławny wyraża przekonanie, że stworzenie wiecznej więzi, opartej na miłości do Boga, jest zależne od woli samych małżonków oraz od innych niezależnych od nich okoliczności. Tłumaczy się to następująco: jeśli dar sakramentu małżeństwa udzielonego i pobłogosławionego przez kapłana zostanie odrzucony z powodu błędu małżonków proszących o ślub, gdy nie byli jeszcze gotowi lub nie byli zdolni do tego, by łaska ta zaowocowała w relacji, Kościół przyjmuje wówczas, że łaska nie została przyjęta i toleruje separację, a także powtórne małżeństwo ${ }^{33}$. Sytuację zerwania więzi między małżonkami doskonale oddają słowa przedstawiciela międzywojennej doktryny prawniczej, stojącej u progu reformy prawa małżeńskiego: „pomimo że trwa jeszcze nadal idealnie sam węzeł prawny, nie wypełniony treścią małżeńskiego życia, które już zamarło" - uznawano, że takie małżeństwo „[j]est małżeństwem bez własnego celu”34. Przyjmuje się jednak, że na płaszczyźnie prawnej małżeństwo prawosławne może zostać rozwiązane, a pomimo tego węzeł sakramentalny pozostaje nienaruszony, bowiem „[1]udzkie rozwiązanie nie likwiduje związku małżeńskiego" ${ }^{\text {"35. }}$.

${ }^{27}$ S. Hrycuniak, Prawosławne pojmowanie małżeństwa, dz. cyt., s. 9.

${ }_{28}$ S. Hrycuniak, Prawosławne pojmowanie małżenstwa, dz. cyt., s. 17.

${ }_{29}$ T. Kałużny, Sakrament małżeństwa w Kościele prawosławnym, [w:] Sakramentalność małżeństwa, red. Z. J. Kijas, J. Krzywda, Kraków 2002, s. 53-55.

${ }^{30}$ Katechizm Kościoła Prawosławnego, Kraków 2001, s. 376.

${ }^{31}$ P. Evdokimov, Prawosławie, tłum. J. Klinger, Warszawa 2003, s. 315.

${ }^{32}$ J. Meyendorff, Małżeństwo w prawosławiu, dz. cyt., s. 18.

33 J. Meyendorff, Małżeństwo w prawosławiu, dz. cyt., s. 45.

${ }^{34}$ Komisja Kodyfikacyjna, Zasady prawa małżeńskiego..., dz. cyt., s. 49.

35 S. Hrycuniak, Prawosławne pojmowanie małżeństwa, dz. cyt., s. 9. 


\section{Rozwód w Statucie Konsystorzy Diecezjalnych Świętego Polskiego Autokefalicznego Kościoła Prawosławnego z 1939 r.}

Jednym z pierwszych dokumentów regulujących prawo rozwiązania małżeństwa w Kościele prawosławnym na ziemiach polskich w okresie międzywojennym był Statut Konsystorzy Diecezjalnych Świętego Polskiego Autokefalicznego Kościoła Prawosławnego zatwierdzony przez Ministra Wyznań i Oświecenia Publicznego w roku $1939^{36}$. Akt ten był pochodną ogłoszonego w 1938 r. Dekretu o stosunku Państwa do Polskiego Autokefalicznego Kościoła Prawosławnego regulującego położenie Kościoła w państwie polskim ${ }^{37}$ oraz Rozporządzenia Rady Ministrów o uznaniu Statutu Wewnętrznego Polskiego Autokefalicznego Kościoła Prawosławnego z 1938 r. $^{38}$

Dekretem potwierdzono niezależność Kościoła prawosławnego od ,jakiejkolwiek pozakrajowej władzy duchownej lub świeckiej” (art. 1). Stwierdzono również, że w życiu wewnętrznym Kościół posiada jednak wolność rządzenia w zakresie przepisów państwowych (art. 2), analogicznie więc w sprawach małżeńskich sądownictwo duchowne posiadało moc orzekania według przepisów kościelnych zgodnych z państwowymi (art. 74).

Władza nad małżeństwem zgodnie ze Statutem Wewnętrznym Polskiego Autokefalicznego Kościoła Prawosławnego stanowiła, że „w sprawach rozwodowych pierwszą instancją sądu kościelnego jest właściwy Konsystorz, drugą i ostatnią - Św. Sobór Biskupi” (\$56). Władza sądów duchownych prawosławnych była już wcześniej znana na ziemiach polskich. Na terenie byłego zaboru rosyjskiego opierała się między innymi na Prawie małżeńskim z 1836 r. ${ }^{39}$

W ówczesnym Statucie konsystorskim podkreślono sakramentalność związku małżeńskiego, który „powinien pozostawać nienaruszalnym dla wszystkich małżonków - chrześcijan prawosławnych" (\$176). Zezwolenie na rozwiązanie

${ }^{36}$ M.P. $1939 \mathrm{nr}$ 136, poz. 319.

37 Dekret Prezydenta Rzeczypospolitej Polskiej z dn. 18 listopada 1938 r. o stosunku Państwa do Polskiego Autokefalicznego Kościoła Prawosławnego (Dz.U. nr 88, poz. 597 z późn. zm.), uchylony.

${ }^{8}$ Dz.U. 1938 nr 103, poz. 679, uchylony.

39 Prawo małżeńskie z 1836 r. wskazywało następujące przyczyny rozwiązania małżeństwa Kościoła grecko-rosyjskiego: rozdzielnie przez nieobecność, przez zesłanie jednego z małżonków (art. 112) oraz rozwód, którego przyczyny regulowało wewnętrzne prawo Kościoła. Artykuł 123 nakazywał, aby sprawy rozwodowe były rozpoznawane przez sądy duchowne, a wyrok zatwierdzany przez Święty Synod. Zasadniczo prawo to obowiązywało do roku 1945. 
małżeństwa w Kościele prawosławnym jest wyrazem idei ekonomii Kościoła, uzasadnionej niedoskonałością człowieka i miłosierdziem; w związku z nią Kościół wydaje zgodę na nowe małżeństwo (\$ 177). Rozwód nigdy nie jest pożądany, bowiem nie jest zgodny z wolą Bożą oraz pozostaje sprzeczny z samym zamysłem małżeństwa, dlatego też niesie ze sobą konsekwencję grzechu cudzołóstwa ${ }^{40}$.

Grzech cudzołóstwa w Kościele podlegał pokucie. Władzę jej nakładania na osoby świeckie posiadały sądy konsystorskie ( $\$ 110 \mathrm{c})$. Nałożenie epitymii mogło nastąpić w przypadku rozwiązania małżeństwa, wówczas bowiem mogło dojść do przewinienia przeciw wierze i moralności (\$154), czego przykład znajdujemy w słowach: „Żona, która opuści męża, jeśli wyjdzie za innego, jest cudzołożnicą" (kan. 87 Sobór Trullański); podobnie traktowany jest ten, kto zawarł małżeństwo niezgodnie z prawem $(\$ 155)$. W takiej sytuacji znajdowały się osoby, które związane były innym małżeństwem lub którym przy rozwodzie zabroniono powtórnego małżeństwa, a także te, które już trzykrotnie zawierały małżeństwo $(\$ 162$ pkt. $4,5,6)$. Implicite w przepisach prawa wewnętrznego pokuta nie była nakładana $\mathrm{z}$ tytułu rozwiązania małżeństwa, dotyczyła okoliczności, które mogły zainicjować rozpad małżeństwa. Winny rozwodu nazywany był cudzołożnikiem, w związku z tym podlegał pokucie kościelnej.

Epitymia w przypadku rozwodu w Kościele prawosławnym pełni znaczącą funkcję. Rozumiana jest jako ćwiczenie pokutne. Kanony soborów powszechnych i lokalnych zawierają odniesienia do „kary epitymii” skierowanej do cudzołożników (kan. 44 Sobór Trullański). Według Paula Evdokimova, prawosławnego teologa, epitymia nie jest jednak formą kary, lecz „środkiem leczącym”, służącym odizolowaniu grzesznika od źródła grzechu ${ }^{41}$. Przepisy kanoniczne Soboru w Ancyrze (kan. 20) na cudzołożnika nakładają siedmioletni czas pokuty mającej charakter stopniowalny. W pierwszym roku pokutnik powinien przebywać wśród płaczących, kolejne dwa lata poświęcić na czytanie Pisma Świętego, trzy lata spędzić wśród klęczących, a w siódmym roku otrzymuje możliwość przystąpienia do Komunii świętej (kan. 87 Sobór Trullański). Zakończenie epitymii umożliwia powrót do wspólnoty kościelnej. W niektórych przypadkach kanony dopuszczają skrócenie pokuty, przykładowo „z uwagi na wiarę i nawrócenie” (kan. 3 Sobór w Neocezarei) lub też gdy małżonkowie „zawarli związek po raz drugi dobrowolnie i zgodnie z prawem, a nie potajemnie, po upływie krótkiego czasu spędzonego na modlitwie

$4^{4}$ S. Hrycuniak, Prawosławne pojmowanie małżeństwa, dz. cyt., s. 9.

${ }^{41}$ P. Evdokimov, Prawosławie, Warszawa 2003, s. 310. 
i poście należy z pobłażliwością przywrócić obcowanie" (kan. 1 Sobór w Laodycei). Podstawę do określenia terminu i trybu pokuty zależnie od popełnionego czynu stanowiły kanony kościelne ( $\$ 156$ Statut).

Polski Autokefaliczny Kościół Prawosławny w omawianym Statucie szczegółowo regulował kwestię ustania małżeństwa. Następowało ono poprzez śmierć fizyczną ( $\$ 176)$ lub duchową jednego z małżonków. W pierwszym wypadku dokonuje się rzeczywiste ustanie pożycia małżeńskiego, $\mathrm{w}$ drugim niemożność jego urzeczywistnienia za życia małżonków i takie małżeństwo może zostać rozwiązane. Paul Evdokimov wskazał „kilka rodzajów śmierci małżeństwa, a tym samym kilka powodów do uzyskania rozwodu, a mianowicie: - śmierć miłości jako materii sakramentu spowodowana przez cudzołóstwo; - śmierć religijna w wyniku odstępstwa od wiary; - śmierć cywilno-prawna (społeczna) na mocy skazania na karę śmierci; - śmierć przez trwającą długo nieobecność" ${ }^{\prime 2}$. Przepisy Kościoła odzwierciedlały tę koncepcję. Przyczynami rozwiązania małżeństwa były: kara dożywotniego więzienia małżonka ( $(180)$ lub brak wiedzy co do miejsca pobytu współmałżonka $(\$ 178)$. W obu sytuacjach następuje fizyczne rozdzielenie małżonków uniemożliwiające realizację celów małżeństwa.

Kanony Soboru Trullańskiego z vir w. odniosły się do problemu cudzołóstwa żony w sytuacji, gdy „mąż jej się oddalił i miejsce jego pobytu jest nieznane oraz gdy brak świadectwa o jego śmierci". Okoliczności prawdopodobieństwa śmierci męża dotyczyły szczególnie żon wojowników lub podróży męża do innych krajów. Zalecano wówczas pobłażliwość wobec postępowania kobiet (kan. 93). W prawie wewnętrznym Polskiego Autokefalicznego Kościoła Prawosławnego z 1939 r. prośba o rozwiązanie małżeństwa oraz zgoda na ponowne małżeństwo w przypadku małżonka zaginionego następowała na wniosek pozostałego małżonka dopiero po uzyskaniu wyroku sądu państwowego o uznaniu zaginionego za zmarłego ( $\$ 182, \S 183$ Statut).

W Statucie znalazł się także katalog przesłanek, w oparciu o które jeden z małżonków mógł wnieść pozew o rozwiązanie małżeństwa, czyli rozwód. Część z nich nawiązywała do przyjętego w Kościele prawosławnym wyjątku cudzołóstwa, uznanego jako dopuszczony przez Jezusa powód rozerwania małżeństwa, a były to: „cudzołóstwo i występki przeciw naturze”, „wstąpienie jednego z małżonków w nowy związek małżeński”, ,złośliwe opuszczenie małżonka

${ }^{42}$ Por. P. Evdokimov, Sakrament miłości. Tajemnica małżeństwa w świetle tradycji prawosławnej, Białystok 2007, s. 206, [za:] T. Kałużny, Nierozerwalność małżeństwa w Kościele prawosławnym, „Sympozjum” 14 (2010) nr 1(19), s. 48. 
przez drugiego współmałżonka”. Pozostałe wynikały bądź z kanonów kościoła lub wyrażały aktualne problemy małżeństw: „odstępstwo od Wiary Prawosławnej [...], niezdolność do współżycia małżeńskiego, jeżeli rozpoczęła się ona przed zawarciem małżeństwa i jest ona przyrodzona; zachorowanie na trąd i syfilis; przymus przy zawieraniu małżeństwa; zamach na życie lub zdrowie współmałżonka albo dzieci lub też znęcanie się nad współmałżonkiem albo jego dziećmi; nieuleczalna i ciężka choroba umysłowa jednego z małżonków; faktyczne ustanie związku małżeńskiego i niemożność urzeczywistniania małżeństwa ze względów na różnicę charakterów małżonków, wskutek której pożycie małżeńskie staje się męczarnią" ( $\$ 185)$. Przesłanki zawarte w Statucie odzwierciedlały również te zamieszczone w Instrukcji o przyczynach rozerwania związku małżeńskiego pobłogosławionego przez Cerkiew. Współcześnie ich listę rozszerzono o chorobę AIDS, medycznie poświadczony alkoholizm lub narkomanię oraz wykonanie aborcji bez wiedzy męża ${ }^{43}$.

Statut konsystorzy z 1939 r. przedstawił w sposób niezwykle precyzyjny kwestię rozwodu małżeństwa prawosławnego; zasadniczo przepisy te były stosowane tylko do wybuchu wojny. Nie można jednak pominąć znaczenia tego dokumentu w odniesieniu do projektów prawa małżeńskiego, które to zmierzały do wprowadzenia instytucji rozwodu dostępnego dla wszystkich obywateli Rzeczpospolitej Polskiej. Problemem było otwarcie drogi do rozwodu małżeństwom katolickim. Krytyka środowisk katolickich, największego wyznania w Polsce, zarzuciła Komisji kodyfikacyjnej brak odniesienia do tradycji chrześcijańskiej, w której winno się szukać kontekstu dla tworzenia prawa. „Woleli operować abstrakcją niż rzeczywistością, gdyż doktryna, którą reprezentują nie wytrzymałaby naporu rzeczywistości”"44. W niniejszej wypowiedzi zabrakło jednak odniesienia do innych Kościołów i związków wyznaniowych równouprawnionych, w tym 4 milionów wiernych Polskiego Autokefalicznego Kościoła Prawosławnego. W dyskursie pojawiały się także głosy przeciwne. Uważano, że państwo, reprezentując porządek przyrodzony, powinno objąć regulacjami ustawowe skutki małżeństwa cywilnego, takie jak np. wspólność majątkową, rejestrację małżeństw, wszystkie te obszary, które

${ }^{43}$ Lokalny Sobór Rosyjskiej Cerkwi Prawosławnej w 1918 r. [w:] J. J. Pawłowicz, Implikacje moralne teologii wspólnoty małżeńsko-rodzinnej w nauczaniu Cerkwi prawosławnej i Kościoła katolickiego. Studium porównawcze, Tuchów 2011, s. 206.

${ }^{44}$ W. Roztworowski, Summum ius-summa iniuria, [za:] S. Biskupski, Nowe prawo matżeńskie w Polsce, „Dziennik Polski” (1931) nr 299, s. 99. 
nie są związane $\mathrm{z}$ węzłem małżeńskim ${ }^{45}$. Ostatecznie rozwód został wprowadzony do systemu prawnego w 1945 r. dekretem Prawo małżeńskie ${ }^{46}$. Akt ten dokonał rozdziału władzy w rozwiązaniu małżeństwa między państwem a Kościołem. W zakresie skutków cywilnych jurysdykcję pełniło państwo, zaś „zdjęcie błogosławieństwa” z małżeństwa prawosławnego pozostało we władzy sądów duchownych Kościoła. Nowa forma nadal wpisywała się w koncepcję prawa małżeńskiego w Kościele prawosławnym.

\section{„Zdjęcie błogosławieństwa” z małżeństwa w wewnętrznym prawie Polskiego Autokefalicznego Kościoła Prawosławnego}

W powojennej Polsce kwestia rozwodów kształtowana była wedle nowej polityki wyznaniowej i społecznej państwa. Dekretem Prawo małżeńskie w 1945 r. wprowadzono instytucję rozwodu małżeństwa. Problematyczne w środowisku katolickim nowe prawo małżeńskie ze świeckim ślubami i rozwodami zostało przyjęte przez Polski Autokefaliczny Kościół Prawosławny. Wsparcia w tej kwestii udzielił państwu metropolita Dionizy, wzywając do podporządkowania się nowym regulacjom, nie zapominając przy tym o zobowiązaniach religijnych ${ }^{47}$. Polski Autokefaliczny Kościół Prawosławny w uchwale Soboru Biskupów z dnia 10 września 1947 r. wyraził otwartość na współpracę Kościoła z państwem, pisząc, iż: „Państwo, jako naturalny objaw życia społecznego, ma swoim zadaniem dobro i szczęście społeczeństwa, osiągnięcie którego jest możliwym tylko przy wspólnym wysiłku wszystkich obywateli, [...] podstawą czego jest chrześcijańska moralność i miłość bliźniego" ${ }^{48}$.

O ile więc dekret małżeński z 1945 r. wniósł możliwość rozwodu cywilnego, o tyle kwestia rozwiązania małżeństwa w Kościele prawosławnym została uregulowana dopiero w Statucie Wewnętrznym Polskiego Autokefalicznego Kościoła Prawosławnego z dnia 23 lutego 1970 r. ${ }^{49}$ Wówczas dopiero swoją moc prawną stracił Statut Wewnętrzny Kościoła z 1938 r. posługujący się jeszcze

45 J. Jaglarz, Problem kodyfikacji prawa małżeńskiego w Polsce, Poznań 1934.

${ }_{46}$ Dekret z dn. 25 września 1945 r. Prawo małżeńskie (Dz.U. nr 48, poz. 270), uchylony.

47 List o kościelnych i cywilnych obowiązkach obywatela Polski wyznania prawosławnego, „Wiadomości Metropolii Prawosławnej w Polsce” (1947) nr 3-12, s. 2-6, [za:] K. Urban, Kościót prawosławny w Polsce 1945-1970, Kraków 1996.

${ }^{48}$ Uchwała Soboru nr 18 z dn. 10 września 1947 r., [za:] K. Urban, Kościół prawosławny..., dz. cyt., s. 334 .

49 Pismo Dyrektora urzędu ds. wyznań z dn. 2.03.1970 r., Warszawa. 
pojęciem rozwodu małżeństwa $(\$ 56)$. W nowym dokumencie Biskupowi Diecezjalnemu przyznano władzę - pierwszej instancji - orzekania w sprawach zdjęcia błogosławieństwa kościelnego ze związku małżeńskiego $(\$ 48)$. Nałożenie błogosławieństwa na małżeństwo zakorzenione było w Tradycji Apostolskiej Kościoła prawosławnego. Nowe przepisy wewnętrzne Kościoła nawiązały do dwuaspektowości małżeństwa. We wczesnym chrześcijaństwie małżeństwo zawierane $\mathrm{w}$ formie cywilnej nadawało znaczenie $\mathrm{w}$ społeczeństwie świeckim. Natomiast dzięki błogosławieństwu biskupa małżeństwo "nabierało również «mocy sakramentalnej», stając się wartością wieczystą, transcendującą ich ziemskie życie, ponieważ zostało «zapisane w niebie», a nie tylko w «urzędzie» świeckim"so . Błogosławieństwo to, udzielane przez kapłana, przez którego działa Bóg, czyni związek sakramentem ${ }^{51} \mathrm{i}$ jest traktowane jako wymóg prawny przy zawarciu małżeństwa ${ }^{52}$.

Zmiany ustrojowe przyniosły nowe przepisy regulujące relację prawną między Rzeczpospolitą Polską a Polskim Autokefalicznym Kościołem Prawosławnym. Były to Ustawa o gwarancjach wolności sumienia i wyznania oraz Ustawa o stosunku RP do Kościoła z 1989 r. ${ }^{53}$ Zgodnie z jej art. 2 ust. 1 tego drugiego dokumentu Kościół posiada autonomię co do swoich spraw wewnętrznych, w których rządzi się własnym prawem i jurysdykcją. Ustawa ta unormowała kwestię instytucji małżeństwa wyznaniowego, czyli zawieranego zgodnie z prawem wewnętrznym Kościoła, podczas którego $\mathrm{w}$ trakcie ceremonii strony oświadczą także wolę jednoczesnego zawarcia małżeństwa podlegającego prawu polskiemu (art. $1 \$ 2$ k.r.o.). Natomiast zdjęcie kościelnego błogosławieństwa z małżeństwa zostało podtrzymane i uregulowane wewnętrznym prawem Kościoła, w tym wypadku Statutem Wewnętrznym Polskiego Autokefalicznego Kościoła Prawosławnego z dnia 10 lutego 1995 r. Z kolei $\$ 24$ odnosi się do jurysdykcji biskupa diecezjalnego w pierwszej instancji nad świeckimi oraz duchownymi osobami „w sprawach dotyczących grzechu przeciwko wierze bogobojności i moralności chrześcijańskiej”. Zgodnie z $\$ 24$ ust. 2 biskup diecezjalny ma prawo do orzeczenia o zdjęciu błogosławieństwa ze związku małżeńskiego. W dotychczasowym

${ }^{50}$ J. Meyendorff, Małżeństwo w prawosławiu, dz. cyt., s. 20.

${ }^{51}$ S. Hrycuniak, Prawosławne pojmowanie matżeństwa, dz. cyt., s. 83.

52 J. Meyendorff, Małżeństwo w prawosławiu, dz. cyt., s. 81.

53 Ustawa z dn. 17 maja 1989 r. o gwarancjach wolności sumienia i wyznania (Dz.U. nr 29, poz. 155 z późn. zm.). Ustawa z dn. 4 lipca 1991 r. o stosunku Państwa do Polskiego Autokefalicznego Kościoła Prawosławnego (Dz.U. nr 66, poz. 287 z późn. zm.). 
prawie wewnętrznym Kościoła niejasna była kwestia przepisów regulujących formę i zasady zdjęcia błogosławieństwa z małżeństwa. Nowy Statut wyraźnie wskazał jedynie, że „Biskupi diecezjalni i Św. Sobór Biskupów sprawują sąd kościelny według kanonów Powszechnego Kościoła Prawosławnego” (\$24). Należą do nich kanony świętych apostołów, kanony Siedmiu Powszechnych i Dziesięciu Lokalnych Soborów, uznane przez Święty Powszechny Kościół Prawosławny, kanoniczne przepisy ojców Kościoła przyjęte przez Sobory Powszechne ( $\$ 2$ ust. 4 Statut 1995). W przypadku, gdy małżonkowie nie zgadzają się z orzeczeniem pierwszej instancji, mogą się odwołać do Świętego Soboru w drugiej i ostatniej instancji ( $\$ 24$ ust. 3 Statut 1995).

Współczesne prawo Polskiego Kościoła Autokefalicznego Prawosławnego odzwierciedla prawosławną myśl teologiczną, w której podkreśla się, że Kościół prawosławny nie ma kompetencji do udzielania rozwodu cywilnego. Uważa się, że orzeczenie sądu cywilnego wraz z zeznaniami małżonków może stanowić tylko podstawę do zdjęcia błogosławieństwa. Rozpad małżeństwa prawosławnego ma bowiem wymiar sakramentalny, czyli duchowy, ponieważ sam związek ma charakter wewnętrzny, a nie zewnętrzny ${ }^{54}$.

Kościół prawosławny pomimo przyzwolenia wiernym na rozwód ma świadomość współczesnego kryzysu trwałości instytucji małżeństwa. Temu zagadnieniu poświęcono uwagę na Wszechprawosławnym Soborze w 2016 r. ${ }^{55}$ W centrum znalazła się kwestia powtórnego małżeństwa. W dokumencie Soboru Wszechprawosławnego „Sakrament małżeństwa i przeszkody jego zawarcia" ${ }^{56}$ nawiązano do „przeszkod[y] drugiego i trzeciego małżeństwa”, których nie można zawrzeć bez unieważnienia lub rozwiązania wcześniejszego małżeństwa (II, 2). Odwołano się do Tradycji Kościoła odnośnie do zgody na rozwiązanie małżeństwa. Nadal uznano je za ustępstwo, odwołując się do Listu św. Pawła o kobiecie, która „po śmierci męża może wprawdzie wyjść

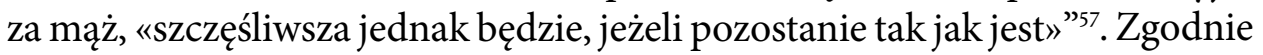
z prawem Kościoła prawosławnego małżeństwo można zawrzeć trzykrotnie, czwarty związek był nieprawny ( $\$ 162$ pkt 7), Sobór Wszechprawosławny potwierdził dotychczasowe stanowisko, że czwarte małżeństwo jest potępiane

${ }^{54}$ S. Hrycuniak, Prawosławne pojmowanie małżeństwa, dz. cyt., s. 26.

55 Wszechprawosławny Sobór odbył się w 2016 r., https://ekai.pl/wydarzenia/ekumenizm/ x101036/na-krecie-zakonczyl-sie-sobor-wszechprawoslawny, 18.01.2017.

${ }^{56}$ Uchwalony dn. 25 czerwca $2016 \mathrm{r}$.

57 J. Piegsa, Małżeństwo sakramentem - rodzina kościołem domowym, Opole 2005, s. 141. 
i odrzucane $(\mathrm{II}, 2)^{58}$. Powtórne małżeństwo traktowane jest w Kościele prawosławnym jako druga szansa, wyrażone to zostało włączeniem w liturgię ukoronowania w nabożeństwo zawarcia małżeństwa. Ta praktyka potwierdza, że prawny formalizm jest odległy myśli prawosławnej, bowiem tradycji kanonistycznej przyświeca wolność, czyli przestrzeń wyboru, którą posiada człowiek. Trafnie wyraził to prawosławny teolog John Meyendorff: „wolność zakłada możliwość grzechu, jak i jego konsekwencji, co w ostateczności może doprowadzić do rozbicia związku małżeńskiego"s9.

\section{Podsumowanie}

Przepisy wewnętrzne Polskiego Autokefalicznego Kościoła Prawosławnego umocowane w dogmatach Powszechnego Kościoła Prawosławnego na przestrzeni niemal wieku ewaluowały w zmieniających się uwarunkowaniach społecznych i politycznych. Analiza przepisów dotyczących rozwiązania małżeństwa prawosławnego pozwala na wskazanie istotnej zmiany w omawianym zakresie. Ze współczesnej perspektywy wydaje się, że wprowadzone do przepisów wewnętrznych Kościoła „zdjęcie błogosławieństwa” z małżeństwa jaśniej oddaje stosunek Kościoła do rozpadu małżeństwa niż pojęcie rozwodu, którym Kościół posługiwał się w przepisach przedwojennych. Zakres i skutek obu czynności prawnych są podobne, celem jest możliwość zawarcia powtórnego małżeństwa. „Zdjęcie błogosławieństwa”, jako wyraz ekonomii kościelnej, jest aktem wyrażającym miłosierdzie Kościoła prawosławnego wobec współczesnego człowieka dokonującego wyboru między małżeństwem a alternatywnymi formami życia rodzinnego.

\section{AbstrakT}

Wyznania chrześcijańskie zasadniczo różnią się w swych poglądach dotyczących rozwiązania małżeństwa poprzez rozwód. Kościół prawosławny, uznając sakramentalność małżeństwa, dopuszcza rozwód oraz wyraża zgodę na zawarcie powtórnego małżeństwa. Istotną rolę w procesie kształtowania się przepisów kościelnych pełni autokefaliczny ustrój Kościoła. Zgodnie z nim kanony kościelne oparte na dogmatach Kościoła prawosławnego muszą być interpretowane w odniesieniu do sytuacji lokalnej

${ }^{8}$ Zob. A. Kuźma, Małżeństwo w projektach dokumentów na Wszechprawosławny Sobór, dz. cyt., s. 177-182.

59 J. Meyendorff, Małżeństwo w prawosławiu, dz. cyt., s. 45. 
Kościoła oraz czasu historycznego. Tak wyznaczona perspektywa prawa wskazuje wrażliwość Kościoła na zmiany społeczne, które także wpływają na sposób interpretacji sytuacji rozpadu małżeństwa. W artykule omówiono statuty wewnętrzne Polskiego Autokefalicznego Kościoła Prawosławnego regulujące zasady rozwiązania małżeństwa od momentu usamodzielnia się Kościoła na ziemiach polskich do czasów współczesnych.

\section{SŁOWA KLUCzowe}

rozwód, Polski Autokefaliczny Kościół Prawosławny, prawo kościelne, zdjęcie błogosławieństwa z małżeństwa

\section{Abstract \\ Divorce in law of the Orthodox Church in Poland: evolution of the institution during the 20th $\mathrm{c}$.}

Christian confessions are differ significantly in their approach to termination of marriage by means of divorce. The Orthodox Church, accepting the sacramental character of marriage, allows for divorce and agrees for marrying again. An important role in shaping of religious norms is played by the autocephalous system within the Church. In accordance with it, the church canons based on the dogmas of the Orthodox Church must be interpreted with respect to the situation of the local church and with respect to the particular point in history. The legal perspective determined in that way indicates the sensitivity of the Church for social changes, which also influence the way termination of marriage is interpreted. The article discusses the internal statutes of the Polish Autocephalous Orthodox Church regulating the rules for terminating the marriage, since the emancipation of the Orthodox Church in Poland until today.

\section{KEY WORDS}

divorce, Polish Autocephalous Orthodox Church, church law, dissolve marriage in church

\section{BIBLIOGRAFIA}

Balejko D., Nowa podstawa prawna Kościoła prawosławnego w państwie polskim, „Przegląd Prawosławny. Organ Polskiego Prawosławia” (1939) nr 1, s. 6-8.

Evdokimov P., Prawosławie, tłum. J. Klinger, Warszawa 2003.

Evdokimov P., Sakrament miłości. Tajemnica małżeństwa $w$ świetle tradycji prawosławnej, Białystok 2007, s. 206, [za:] T. Kałużny, Nierozerwalność małżeństwa w Kościele prawosławnym, „Sympozjum” 14 (2010) nr 1(19), s. 41-6o. 
Główny Urząd Statystyczny, Historia Polski w liczbach, red. C. Kuklo, J. Łukasiewicz, C. Leszczyńska, Warszawa 2014.

Hrycuniak S., Prawosławne pojmowanie małżeństwa, Białystok 1994.

Hryniewicz W., Zasada „ekonomii eklezjalnej” w życiu i teologii prawosławia, „Roczniki Teologiczno-Kanoniczne" 28 (1981) z. 6, s. 137-152.

Jaglarz J., Problem kodyfikacji prawa małżeńskiego w Polsce, Poznań 1934.

Kałużny T., Sakrament małżeństwa w Kościele prawosławnym, [w:] Sakramentalność małżeństwa, red. Z. J. Kijas, J. Krzywda, Kraków 2002, s. 53-71.

Katechizm Kościoła Prawosławnego, Kraków 2001.

Komisja Kodyfikacyjna, Zasady prawa matżeńskiego uchwalone przez komisję kodyfikacyjna, Warszawa 1929.

Kuźma A., Małżeństwo w projektach dokumentów na Wszechprawosławny Sobór, „ELIPS” 18 (2016), s. 177-182.

L. Z., Śladem dawnej tradycji, „Przegląd Prawosławny. Organ Polskiego Prawosławia” (1939) $\mathrm{nr}$ 1, s. 5.

List o kościelnych i cywilnych obowiązkach obywatela Polski wyznania prawosławnego, „Wiadomości Metropolii Prawosławnej w Polsce” (1947) nr 3-12, s. 2-6.

Meyendorff J., Małżeństwo w prawosławiu, tłum. K. Leśniewski, Lublin 1995.

Papierzyńska-Turek M., Między tradycją a rzeczywistością. Państwo wobec prawosławia 1918-1939, Warszawa 1989.

Pawłowicz J. J., Implikacje moralne teologii wspólnoty małżeńsko-rodzinnej w nauczaniu Cerkwi prawosławnej i Kościoła katolickiego. Studium porównawcze, Tuchów 2011.

Piegsa J., Małżeństwo sakramentem - rodzina kościołem domowym, Opole 2005.

Pismo Święte Starego i Nowego Testamentu. Biblia Tysiąclecia, Poznań 1986.

Płoński T., Tomosy z 1924 i 1948 roku nadające status autokefaliczny Polskiemu Autokefalicznemu Kościołowi Prawosławnemu: ich wydźwięk historyczno-kanoniczny, „Studia Warmińskie” 46 (2009), s. 153-171.

Przekop E., Problem wspólnego Kodeksu Prawa Kanonicznego dla kościołów prawosławnych, „Studia Płockie” (1977), s. 173-183.

Roztworowski W., Summum ius-summa iniuria, za: S. Biskupski, Nowe prawo matżeńskie w Polsce, „Dziennik Polski” (1931) nr 299, s. 99.

Strzebińczyk J., Prawo rodzinne, Warszawa 2013.

Szukalski P., Małżeństwo. Początek i koniec, Łódź 2013.

Wojciechowski M., Oddalenie żony czy rozwód? Język Biblii a dzisiejsze postrzeganie małżeństwa i jego rozpadu, „Forum Teologiczne” 13 (2012), s. 39-51.

Wronkowska S., Ziembiński Z., Zarys teorii prawa, Poznań 2011.

Znosko A., Kanony kościoła prawosławnego, Hajnówka 2000. 


\section{Akty prawne}

Dekret z dn. 25 września 1945 roku. Prawo małżeńskie (Dz.U. nr 48, poz. 270), uchylony.

Dekret Prezydenta Rzeczypospolitej z dn. 18 listopada 1938 r. o stosunku Państwa do Polskiego Autokefalicznego Kościoła Prawosławnego (Dz.U. nr 88, poz. 597), uchylony.

Pismo Dyrektora urzędu ds. wyznań w sprawie uznania Statutu Wewnętrznego Polskiego Kościoła Prawosławnego uchwalonego przez Sobór Biskupów w dniu 23 lutego 1970 r., z dn. 2.03.1970 r., Warszawa.

Rozporządzenia Rady Ministrów o uznaniu Statutu Wewnętrznego Polskiego Autokefalicznego Kościoła Prawosławnego z dn. 10 grudnia 1938r. (Dz.U. nr 103, poz. 679), uchylony.

Uchwała Soboru nr 18 z dn. 10 września $1947 \mathrm{r}$.

Ustawa $\mathrm{z}$ dn. 17 maja 1989 r. o gwarancjach wolności sumienia i wyznania (Dz.U. nr 29, poz. 155 z późn. zm.).

Ustawa z dn. 25 lutego 1964 r. Kodeks rodzinny i opiekuńczy (Dz.U. nr 9, poz. 59 z późn. $\mathrm{zm}$.).

Ustawa z dn. 4 lipca 1991 r. o stosunku Państwa do Polskiego Autokefalicznego Kościoła Prawosławnego (Dz.U. nr 66, poz. 287 z późn. zm.).

Zarządzenie Ministra Wyznań Religijnych i Oświecenia Publicznego z dnia 6 maja 1939 r. w sprawie zatwierdzenia Statutu Konsystorzy Św. Polskiego Autokefalicznego Kościoła Prawosławnego (M.P. nr 136, poz. 319), uchylony.

Statut Wewnętrzny Polskiego Autokefalicznego Kościoła Prawosławnego z dn. 23 lutego 1970 roku, uchylony.

Statut Wewnętrzny Polskiego Autokefalicznego Kościoła Prawosławnego z dn. 10 lutego 1995 roku. 